\title{
Foreword
}

\section{Four Arrows}

The Foreword of a book, when written by an invited guest, usually proffers why the text is being written now. If I were to try to accomplish this in one sentence, I might say something like: "This book is about how Transformative Phenomenology can be a methodology and a way to bring forth life-affirming cultures to replace or overshadow death-affirming ones that currently have us at the edge of extinction." Such a single sentence, however, would not do justice to the chapters that follow. For transformational learning to take place on the scale the editors and contributors intend, one sentence could never convey the goals and urgency of this text's editors and contributors. They are too complex, holistic, intuitive, and too mystical for a single sentence. So, I will continue writing for a while.

I'm not the first to suggest alignment between phenomenology and mysticism, and I am guessing one reason I was invited to write this Foreword relates to my own mystical orientation as an Indigenous-based scholar. If we define a mystic as one who believes in the spiritual apprehension of truths that are beyond the intellect, then this well describes the Indigenous worldview that umbrellas the great diversity of place-based knowledge traditional First Nation wisdom keepers may possess:

Mysticism, although differently expressed in particular Indigenous lifeways, manifests the intimate relatedness of person, community, spirits and ecosystem. This interactive quaternity is ritually embedded in Indigenous lifeways and symbolically unfolded in cosmological narratives.

(Grim 2020, p. 114)

Valerie Bentz, and others associated with this book, have recognized the power of traditional Indigenous wisdom and spirituality. She was especially interested by my assertion that there are only two worldviews (Four Arrows 2016) - the Indigenous that guided us for $99 \%$ of human history, and the Dominant one that has essentially guided us for the past $1 \%$, or approximately 9,000 years, with the Americas suffering the most during the past 600 years or so. The father of social-anthropology, Robert Redfield, proposed this idea in the 1940s (Redfield 1952, 1956). He also felt that the new worldview's oppression and disregard for the Indigenous worldview would prove to be one of the great human tragedies. Perhaps he was among the first academics to notice Deathworlds within Lifeworlds and Deathworlds overtaking Lifeworlds. Genocide and culturecide against Indigenous Peoples continues today. 
This brief history implies that, rather than reinventing the proverbial wheel from scratch, Collaborative Transformative Phenomenology might utilize Indigenous worldview precepts in its various explorations on behalf of eradicating the Deathworlds all around us. Indeed, one might merely look at the contrasting and potentially complementary dualities that exist between dominant and Indigenous consciousness and lifeways. This can be done by peeking at the list of 40 pairings printed in Chapter One of this book that I have shared from my book The Red Road: Linking Diversity and Inclusion Initiatives to Indigenous Worldview (2020). It does not take much consideration to realize connections between Deathworlds and adherence to personal and institutional assumptions and policies based on such characteristics of the Dominant Worldview as:

- dualistic thinking without seeking complementarity

- acceptance of rigid hierarchies

- fear-based thoughts and behaviors

- living without a strong social purpose

- primarily selfish goals for personal gain

- rigid and discriminatory gender stereotypes

- uncritical acceptance of materialism

- anthropocentric and not honoring the Earth as Sentient and Sacred

- unfamiliarity with an alternative consciousness

- disregarding holistic interconnectedness

- emphasis on theory and rhetoric versus action

- acceptability of dishonesty and deception

- seeing ceremony as a rote phenomenon

- autonomy not connected to the group

Although the contributors to this text may or may not refer directly to Indigenous worldview in each chapter, the reader might imagine how approaches to Lifeworld and Deathworld applications can be further enriched by noting which worldviews in the list may apply here or there. In other words, aspects of consciousness, experience and transformation relating to Lifeworlds versus Deathwords might be also seen as relating to the inability of people to notice the proverbial water in which we swim I describe as "worldview." At the same time, one might easily align the dominant worldview side of the list with the cultivation and preservation of Deathworlds. Moreover, with the deep insights that phenomenology can evoke, the worldview precepts can be used to help with metacognitive transformations or at least recognizing possibilities for complementarity between opposing views.

Note that, at least as relates to ecological harmony, claims about the importance of such worldview reflection are increasingly being acknowledged. The 
largest study ever done, the United Nations Biodiversity and Extinction Rate Report released in May of 2019, using 450 researchers from 50 countries going over more than 15,000 peer-reviewed papers, revealed that where Indigenous worldview operates, extinction rates are absent or minimal (Four Arrows 2019). Yet it may be that in order for enough people to come to terms with this, they must collectively engage in reflection, storytelling, and dialogue about the phenomenon of worldview and its relationship to Life- and Deathworlds. If the reader is able to learn from these chapters about phenomenology accordingly, this book and its timeliness will serve as a culminating event that builds on the work of Edmund Husserl and his 1936 text, The Crisis of European Sciences and Transcendental Phenomenology. Referring to Lifeworld as a contextual context for phenomenology, he reveals a concern about declining moral, political and scientific integrity. More than 50 years later, Jürgen Habermas went a little further, explaining how Lifeworld can be distorted by unjustifiable authority and human rationalization of colonization (1981). In 2003, Achille Mbembe wrote about "the creation of death-worlds, new and unique forms of social existence in which vast populations are subjected to conditions of life conferring upon them the status of living dead” (p. 14). Five years later, Rehorick and Bentz write a book about "transformative phenomenology" and how it can be used to change our Lifeworlds (2008). A decade later, Bentz, Rehorick, Marlatt, Nishii and Estrada published a piece in a research journal about how "transformative phenomenology” can be an antidote to Deathworld-making (2018).

And now, Collaborative Transformative Phenomenology, in joining with the Indigenous Worldview, may have finally come to realize the most invisible source - worldview - and its role in using phenomenological awareness to bring our world back into harmony.

\section{References}

Bentz, Valerie/Marlatt, James/Nishi, Ayumi/Estrada, Carol (2018): “Transformative Phenomenology as an Antidote to Technological Deathworlds”. In: Schutzian Research 10, pp.189-220.

Four Arrows (2016): Point of Departure: Returning to Our More Authentic worldview for Education and Survival. Charlottesville: Information Age Publishing.

Four Arrows (2019): “The Media Have Missed a Crucial Message of the UN's Biodiversity Report”. Retrieved from https://www.thenation.com/article/archive/biodiversity-unreport-indigenous-worldview/, visited October 13, 2020.

Grim, John (2020): “Cosmology and Native North American Mystical Traditions”.

In: Theologique 1, pp. 113-142. 
Habermas, Jürgen (1985): The Theory of Communicative Action: Lifeworld and System, A Critique of Functionalist Reason (T. McCarthy, Trans.). Boston: Beacon.

Mbembe, Joseph-Achille (2003): “Necropolitics.” In: Public Culture 15. No.1, pp. 11-40.

Redfield, Robert (1952): The Primitive World View. Proceedings of the American Philosophical Society 96. No.1, pp. 30-36.

Redfield, Robert (1956): Peasant Society and Culture: An Anthropological Approach to Civilization. Chicago: University of Chicago Press.

Rehorick, David/Bentz, Valerie (Eds.) (2008): Transformative Phenomenology: Changing Ourselves, Lifeworlds and Professional Practice. New York: Lexington. 